\title{
METHODS FOR MANAGING TEXTURAL PROPERTIES OF NANOPOWDERS TO CREATE A DRUG DELIVERY SYSTEM BASED ON SiO ${ }_{2}, \mathrm{SiO}_{2}-\mathrm{MnO}_{2}$
}

\author{
O. A. Zlygosteva ${ }^{1,2^{*}}$, S. Yu. Sokovnin ${ }^{1,2}$, V. G. Ilves ${ }^{2}$ \\ ${ }^{1}$ Ural Federal University, Ekaterinburg, Russia \\ ${ }^{2}$ Institute of Electrophysics of the Ural Branch of RAS, Ekaterinburg, Russia
}

\begin{abstract}
The physical and chemical properties of nanomaterials depend not only on the nature of the substance, but also on the size and shape of the particles, as well as the size and shape of the pores. In this paper, the methods for managing the textural properties of $\mathrm{SiO}_{2}, \mathrm{SiO}_{2}-\mathrm{MnO}_{2}$ nanopowders, produced by pulsed electron beam evaporation in vacuum, are investigated. The researched methods include doping at the stage of preparation and ultrasonic treatment of aqueous nanopowder suspensions. In addition, the radiation of $\mathrm{CaF}_{2}$ nanopowders by relativistic electrons was considered as a potential method for managing properties.
\end{abstract}

Keywords: Nanopowders, silica, nanofluorides, managing properties, surface area, porosity, doping, electron irradiation

\section{INTRODUCTION}

Today, nanomaterials are widely used in various industries, and due to their size compared to cells in various fields of biotechnology, medicine and pharmaceutics $[1,2]$.

The use of nanopowders (NP) directly depends on their textural properties, such as the specific surface area $\left(\mathrm{S}_{\mathrm{BET}}\right)$, nanoparticle size and shape, as well as size, volume and shape of pores [3]. The ability to control these parameters will make it possible to select the optimal properties of materials and thereby expand the applications of the NP.

An important developing application of the oxide NP is a targeted drug delivery [4, 5]. For an effective delivery, it is necessary to achieve the maximum loading capacity of the nanocarrier to encapsulate the required therapeutic dose of the drug in a smaller mass of carrier substance. The loading capacity is directly determined by the porosity and SвEт [6].

The properties of the NP significantly depend on the method of synthesis. There are several methods for the production of NP, such as chemical, biological and physical methods [7]. One of the important advantages of physical methods is the absence of toxic chemicals at the production stage, which could be adsorbed on the NP surface. This subsequently can cause an adverse effect on organisms in medical applications and interaction of these chemicals with drugs.

In this work, a physical method is used to produce a $\mathrm{NP}$ by pulsed electron beam evaporation (PEBE) of targets in a low-pressure gas $(4 \mathrm{~Pa})[8]$.
In addition to managing properties at the stage of NP production, there are several ways to control the textural properties of the NP after the synthesis process including external physical action or surface modification with chemical molecules.

Thus, the size and shape of the particles and pores are controlled both at the stage of NP production and by the additional physicochemical effects on the NP.

The purpose of this work is to study various methods for managing the textural properties of $\mathrm{SiO}_{2}$, $\mathrm{SiO}_{2}-\mathrm{MnO}_{2}$ and $\mathrm{CaF}_{2}$ nanopowders.

\section{THE RESEARCH OF THE METHODS FOR MANAGING TEXTURAL PROPERTIES OF NP}

In this work, three methods were considered: doping of the basic material at the stage of preparing targets for evaporation in the process of NP production; physical effects on the produced NP as the external ultrasonic (US) treatment of NP aqueous suspensions and electron irradiation of NP.

\subsection{Managing the properties of NP by doping}

For the production of targets, submicron powders of silicon dioxide (Aerosil 90) and manganese dioxide (GOST 4470-79), in a mass concentration of manganese dioxide 0.1, 1, 3 and $5 \%$, were mixed and then pressed on a hand press into round targets with a diameter of about $40 \mathrm{~mm}$, thickness up to $10 \mathrm{~mm}$.

The targets were evaporated by the PEBE method in a low-pressure gas at a NANOBIM-2 installation. Evaporation mode: voltage - $38 \mathrm{kV}$, pulse duration

*zlygosteva13@mail.ru 
$\sim 100 \mu \mathrm{s}$, pulse repetition rate 50 - 100 pps. The evaporation time was $15-30$ minutes. After evaporation, the NP was collected in a chamber with installed glasses placed around the target at a distance of about 10-15 cm to prevent uncontrolled doping of the NP with the crystallizer material. Further, the glasses were removed from the evaporation chamber, and the NP was scraped off the surface using the Ti foil.

The NP composition was determined by X-ray diffraction analysis on an XRD 7000 diffractometer, the $S_{\mathrm{BET}}$, volume and pore size were measured using a BET-BJH Tristar 3000 V6.03 (Micrometrics, USA).

The XRD analysis showed that NP $\mathrm{SiO}_{2}-\mathrm{MnO}_{2}$ produced by the method of PEBE were completely amorphous [9]. The hysteresis loops on the magnetization curves of $\mathrm{SiO}_{2}-\mathrm{MnO}_{2} \mathrm{NP}$ demonstrated that NP with all dopant concentrations had ferromagnetic properties. However, the increase of the ferromagnetic response was observed with the increase of manganese dioxide concentration [9]. This effect could be caused by structural defectiveness due to doping the pure $\mathrm{SiO}_{2}$.

The produced NP morphology was examined by microscopy on a JEM 2100 transmission microscope. The data of microscopic analysis (Fig. 1) showed that $\mathrm{SiO}_{2}-\mathrm{MnO}_{2} \mathrm{NP}$ are presented in the form of agglomerates with interparticle porosity, similar to pure $\mathrm{SiO}_{2} \mathrm{NP}$ (Fig. 2) [10].

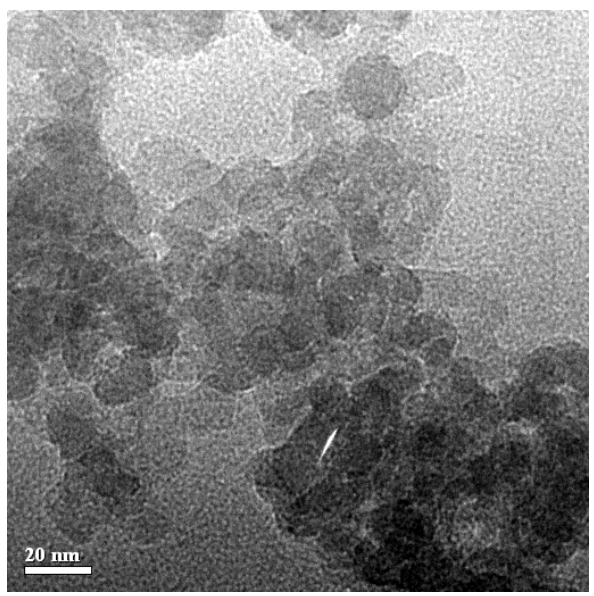

Figure 1. TEM picture of $\mathrm{SiO}_{2}-3 \% \mathrm{MnO}_{2} \mathrm{NP}$

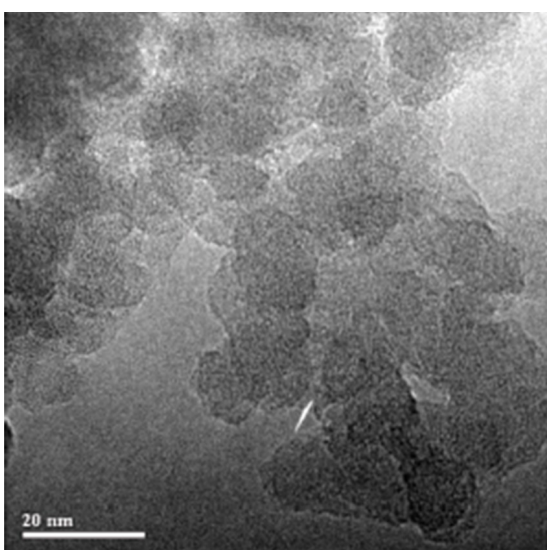

Figure 2. TEM picture of $\mathrm{SiO}_{2} \mathrm{NP}[10]$
According to the BET analysis (Table 1), the nonlinear change of properties (pore size and volume) was observed with the increase of the dopant concentration with the presence of the maximum of properties in $\mathrm{SiO}_{2}-3 \% \mathrm{MnO}_{2} \mathrm{NP}$.

$\mathrm{S}_{\text {BET }}$ decreased in the samples with a small concentration of the dopant, while a further increase in the dopant concentration led to an increase in $\mathrm{S}_{\mathrm{BET}}$.

The number of pores in the surface area was estimated. For this, the ratio of the specific pore volume of the samples and the surface area of one pore was calculated based on the pore sizes in an approximation to the spherical shape.

It was established that the number of pores decreased from 11.5 to $5.7^{*} 10^{17}$ pc. in $\mathrm{SiO}_{2}$ and $\mathrm{SiO}_{2}{ }^{-}$ $0.1 \% \mathrm{MnO}_{2}$, respectively, which may explain the decrease in SвET. A further increase in the dopant concentration to $5 \%$ led to an increase in the number of pores to $13^{*} 10^{17} \mathrm{pc}$.

The proportion of the pore area does not exceed $15 \%$ of the total sample area, with the maximum in the sample with a $3 \%$ dopant concentration, at which the maximum in size and pore volume was studied.

Table 1. Textural properties of NP

\begin{tabular}{|l|c|c|c|}
\hline Sample & $\begin{array}{c}\mathrm{S}_{\mathrm{BET}^{1}}, \\
\mathrm{~m}^{2} / \mathrm{g}\end{array}$ & $\begin{array}{c}\mathrm{D}_{\mathrm{BJH}}{ }^{2}, \\
\mathrm{~nm}\end{array}$ & $\begin{array}{c}\mathrm{V}_{\mathrm{p}_{\text {-total }}{ }^{3},} \\
\mathrm{~cm}^{3} / \mathrm{g}\end{array}$ \\
\hline $\mathrm{SiO}_{2}$ & 125.4 & 18.6 & 0.36 \\
$\mathrm{SiO}_{2}-0.1 \% \mathrm{MnO}_{2}$ & 75.8 & 20.6 & 0.36 \\
$\mathrm{SiO}_{2}-1 \% \mathrm{MnO}_{2}$ & 88.9 & 22.1 & 0.33 \\
$\mathrm{SiO}_{2}-3 \% \mathrm{MnO}_{2}$ & 134.2 & 26.4 & 0.88 \\
$\mathrm{SiO}_{2}-5 \% \mathrm{MnO}_{2}$ & 176.4 & 20.8 & 0.52 \\
\hline
\end{tabular}

${ }^{1} \mathrm{~S}_{\mathrm{BET}}$ - BET specific surface area, ${ }^{2} \mathrm{D}_{\mathrm{BJH}}$ - pore diameter by $\mathrm{BJH}$ desorption, ${ }^{3} \mathrm{~V}_{\mathrm{p} \text {-total }}$ - total pore volume.

The doping process can cause textural changes that can be associated with the appearance of defects in the structure during the interaction of manganese and oxygen atoms in silica with the formation of electroneutral chemically-related complexes in the lattice.

Thus, SBET managing is possible by doping the material at the target preparation stage (PEBE method of NP production) due to an increase in the defectiveness of the structure with an increase in the dopant concentration.

\subsection{Managing the properties of NP by US-}

treatment

For developing a pharmaceutical delivery system, NP are transferred into a suspension form, which allows the system to be introduced into the body (for example, intravenously). This also increases the contact area with the surface of the tissues and, accordingly, increases the therapeutic effect. Thus, it is necessary to investigate the possibility of managing the textural properties of NP in suspension form.

Typically, NP suspensions are prepared by adding NP to distilled water. The concentration of NP suspensions was $0.5^{-2} \mathrm{mg} / \mathrm{ml}$.

To study the effect of the US-treatment on the textural properties of NP, samples of NP suspensions 
were sonicated in an ultrasonic bath PSB-2835-05 100 $\mathrm{W}$ for $\mathrm{t}=20,40,60$ and $100 \mathrm{~min}$.

After sonication, the samples were centrifuged in an AllegraX-30 Centrifuge (3000 rpm, $10 \mathrm{~min}$.) to separate the NP from the supernatant; then the NP were dried (at $40^{\circ} \mathrm{C}$ ) for 72 hours. For these samples, the analysis of textural properties was conducted (Table 2).

The data in Table 2 showed that the SBET and porosity (both the volume and pore size) of pure $\mathrm{SiO}_{2}$ NP monotonously decreased with the increased sonication time.

The SBET and porosity of the doped samples (Table 2) also decreased after sonication relative to the textural properties of NP that did not undergo the UStreatment, which demonstrates the ability to manage textural properties using US.

Table 2. Textural properties of sonicated NP

\begin{tabular}{|l|c|c|c|c|}
\hline Sample & $\begin{array}{c}\text { D ВJн, } \\
\mathrm{nm}\end{array}$ & $\begin{array}{c}\mathrm{S}_{\mathrm{BET}}, \\
\mathrm{m}^{2} / \mathrm{g}\end{array}$ & $\begin{array}{c}\mathrm{V}_{\mathrm{p} \text {-total, }} \\
\mathrm{cm}^{3} / \mathrm{g}\end{array}$ & $\begin{array}{c}\mathrm{t}, \\
\mathrm{min} .\end{array}$ \\
\hline $\mathrm{SiO}_{2}{ }^{*}$ & 18.6 & 125.4 & 0.36 & $\mathrm{o}$ \\
$\mathrm{SiO}_{2}$ & 16.5 & 88.2 & 0.28 & 40 \\
$\mathrm{SiO}_{2}$ & 16.0 & 55.5 & 0.20 & 100 \\
$\mathrm{SiO}_{2}-1 \% \mathrm{MnO}_{2}{ }^{*}$ & 22.1 & 88.9 & 0.33 & 0 \\
$\mathrm{SiO}_{2}-1 \% \mathrm{MnO}_{2}$ & 16.5 & 120.1 & 0.39 & 20 \\
$\mathrm{SiO}_{2}-1 \% \mathrm{MnO}_{2}$ & 21.8 & 40.7 & 0.12 & 40 \\
$\mathrm{SiO}_{2}-3 \% \mathrm{MnO}_{2}{ }^{*}$ & 26.4 & 134.2 & 0.88 & 0 \\
$\mathrm{SiO}_{2}-3 \% \mathrm{MnO}_{2}$ & 13.7 & 53.4 & 0.20 & 40 \\
$\mathrm{SiO}_{2-5} \mathrm{MnO}_{2}{ }^{*}$ & 20.8 & 176.4 & 0.52 & 0 \\
$\mathrm{SiO}_{2-5} \mathrm{MnO}_{2}$ & 18.7 & 151.9 & 0.33 & 60 \\
\hline
\end{tabular}

* non-suspended NP samples after production.

The mechanism of the US-treatment influence on the NP structure has not been sufficiently studied. It can be assumed that, as a result of the US-treatment, agglomerates are destroyed with the formation of the smaller and compacted structures. Moreover, the obtained results for pure and doped $\mathrm{SiO}_{2} \mathrm{NP}$ differ, which indicates a reduced strength of the agglomerates of doped samples. At the same time, the samples doped with $1 \%$ and $3 \% \mathrm{MnO}_{2}$ lose in SBET more quickly, which indicates lower agglomerate strength of the samples with low concentrations of the dopant.

Thus, the US-treatment of NP suspensions is a prospective method for managing the NP properties, but additional research is required to identify the dependences more precisely and choose the optimal processing mode.

2.3. Managing the properties of NP by irradiation with relativistic electrons

The $\mathrm{CaF}_{2} \mathrm{NP}$ are promising materials for the use in biomedicine [11]. The $\mathrm{CaF}_{2} \mathrm{NP}$ were also produced by the PEBE method in vacuum.

The samples were irradiated by a nanosecond relativistic electron beam on a pulsed-periodic accelerator URT-1M [12]. The absorbed doses on the surface of the samples were 31.5 and $63 \mathrm{MGy}$.
According to the results, the irradiation of the $\mathrm{CaF}_{2}$ NP led to a significant increase of up to 1.5 times in the SBET of the NP (Table 3).

Table 3. Textural properties of irradiated $\mathrm{CaF}_{2} \mathrm{NP}$

\begin{tabular}{|c|c|c|c|}
\hline $\mathrm{AD}, \mathrm{MGy}$ & $\mathrm{S}_{\text {BET }}, \mathrm{m}^{2} / \mathrm{g}$ & $\mathrm{V}_{\mathrm{p} \text {-total }}, \mathrm{cm}^{3} / \mathrm{g}$ & Dвлн, $\mathrm{nm}$ \\
\hline o & $64 \cdot 3$ & 0.25 & 21 \\
\hline 31.5 & 79.8 & 0.52 & 27.9 \\
\hline 63 & 91.49 & 0.46 & 25.2 \\
\hline
\end{tabular}

Furthermore, electron irradiation unexpectedly affects the total volume and the average pore diameter: an increase and normalization of these parameters is observed, especially at the dose of 31.5 MGy.

Thus, it was found that irradiation with relativistic electrons can be considered as the method for managing the textural properties of the NP.

\section{CONCLUSION}

In this work, various methods for managing the textural properties of the NP were studied.

It was shown that doping at the stage of preparing targets for evaporation during the NP production process allows managing the SBET, pore size and volume. Generally, the porosity of samples increases with the increase of dopant concentration.

Two methods for managing the textural properties of the produced NP have been proposed - the UStreatment of aqueous suspensions of NP followed by centrifugation and drying results in a decrease in porosity and SвEт. As the sonication time increases, the $\mathrm{S}_{\text {BET }}$ and porosity of the $\mathrm{SiO}_{2}$ samples decrease monotonically. The porosity and $\mathrm{S}_{\mathrm{BET}}$ of the doped samples also decrease after the US-treatment relative to the textural properties of the non-treated NP.

On the contrary, the irradiation of NP with relativistic electrons leads to an increase in the $\mathrm{S}_{\mathrm{BET}}$, total volume and average pore diameter. Moreover, the irradiation of the NP leads to the normalization of the textural properties of the NP.

Thus, it is necessary to continue the study of the methods for managing the properties of NP, especially the electron irradiation method, to expand the applications of NP. Furthermore, the methods for managing the properties of the already produced NP are of particular interest, because this can allow repeatedly varying the NP properties for a particular application after synthesizing.

Acknowledgements: The work was performed within the framework of the Federal Task No. O3892015-0026 and supported, in part, by the Russian Foundation for Basic Research (Project No. 18-o8oo514).

\section{REFERENCES}

1. Z. Li, J. C. Barnes, A. Bosoy, J. F. Stoddart, J. I. Zink, "Mesoporous silica nanoparticles in biomedical applications," Chem. Soc. Rev., vol. 41, no. 7, pp. 2590 2605, Apr. 2012. 
DOI: $10.1039 / \operatorname{ccs} 15246 \mathrm{~g}$

PMid: 22216418

2. Q. A. Pankhurst, J. Connolly, S. K. Jones, J. Dobson, "Applications of magnetic nanoparticles in biomedicine," J. Phys. D, vol. 36, no. 13, pp. $167-181$, Jun. 2003.

DOI: $10.1088 / 0022-3727 / 36 / 13 / 201$

3. S. Horikoshi, N. Serpone, "Introduction to Nanoparticles," in Microwaves in nanoparticle synthesis: Fundamentals and applications, $1^{\text {st }}$ ed., Berlin, Germany: Wiley-VCH, 2013, ch. 1, pp. 1 - 24.

DOI: $10.1002 / 9783527648122$

4. M. Arruebo, R. Fernández-Pacheco, M. R. Ibarra, J. Santamaría, "Magnetic nanoparticles for drug delivery," Nano Today, vol. 2, no. 3, pp. 22 - 32, Jun. 2007. DOI: 10.1016/S1748-0132(07)70084-1

5. O. A. Zlygosteva, S. Y. Sokovnin, V. G. Ilves, "The use of manganese-doped mesoporous silica nanopowder for targeted drug delivery," J. Phys. Conf. Ser., vol. 1115, 2018.

DOI: $10.1088 / 1742-6596 / 1115 / 4 / 042067$

6. Y. Li et al., "Hollow Mesoporous Silica Nanoparticles with Tunable Structures for Controlled Drug Delivery," ACS Appl. Mater. Interfaces, vol. 9, no. 3, pp. 2123 2129, Jan. 2017.

DOI: $10.1021 /$ acsami.6b13876

PMid: 28004570

7. S. Iravani, H. Korbekandi, S. V. Mirmohammadi, B. Zolfaghari, "Synthesis of silver nanoparticles: chemical, physical and biological methods," Res. Pharm. Sci., vol. 9, no. 6, pp. 385-406, Nov-Dec. 2014. PMid: 26339255 PMCid: PMC4326978

8. S. Y. Sokovnin, V. G. Il'ves, M. G. Zuev, "Production of complex metal oxide nanopowders using pulsed electron beam in low-pressure gas for biomaterials application," in Engineering of Nanobiomaterials: Applications of Nanobiomaterials, vol. 2, A. M. Grumezescu, Eds., 1st ed., Amsterdam, Netherlands: Elsevier Inc., 2016, ch. 2, pp. 29 - 75 . DOI: 10.1016/C2015-0-00356-2

9. О. А. Злыгостева, С. Ю. Соковнин, В. Г. Ильвес, “Оценка свойств мезопористого диоксида кремния, допированного диоксидом марганца, полученного импульсным электронным испарением, для применения в биомедицине,” Физико-химические аспекты изучения кластеров, наноструктур и наноматериалов: межвуз. сб. науч. тр., т. 9, стр. 199 204, 2017. (O. A. Zlygosteva, S. Yu. Sokovnin, V. G Il'vec, "Properties evaluation of mesoporous silica nanopowders doped with manganese dioxide produced by a pulsed electron beam evaporation for biomedical applications," Phys. Chem. Asp. Study of Clust., Nanostruct. Nanomater.: Collect. Pap., vol. 9, pp. 199 - 204, 2017.)

DOI: $10.26456 /$ pcascnn/2017.9.199

10. V. G. Il'ves, M. G. Zuev, S. Y. Sokovnin, "Properties of Silicon Dioxide Amorphous Nanopowder Produced by Pulsed Electron Beam Evaporation," J. Nanotechnol., vol. 2015, no. 18, pp. 1 - 8, Oct. 2015.

DOI: $10.1155 / 2015 / 417817$

11. P. Tian et al., " $\mathrm{TiO}_{2} / \mathrm{CaF}_{2}$ composite coating on titanium for biomedical application," Mater. Lett. vol. 117, pp. 98 - 100, Feb. 2014. DOI: 10.1016/j.matlet.2013.12.006

12. S. Y. Sokovnin, M. E. Balezin, "Repetitive nanosecond electron accelerators type URT-1 for radiation technology," Radiat. Phys. Chem., vol. 144, pp. 265 - 270, Mar. 2018.

DOI: 10.1016/j.radphyschem.2017.08.023 